\title{
A LowCost Pyrolysis Oil Production From Microalgae
}

\section{Suppalerk Aramkitphotha}

Technopreneurship and Innovation Management, Chulalongkorn University, Bangkok 10330, Thailand.

Correspondence Author: Suppalerk Aramkitphotha, Technopreneurship and Innovation Management, Chulalongkorn University, Bangkok 10330, Thailand.

Received date: 11 April 2018, Accepted date: 25 July 2018, Online date: 8 August 2018

Copyright: (C) 2018 Suppalerk Aramkitphotha. This is an open-access article distributed under the terms of the Creative Commons Attribution License, which permits unrestricted use, distribution, and reproduction in any medium, provided the original author and source are cre dited.

\begin{abstract}
Microalgae are one of most interesting sources of renewable energy due to high growth rate, no land competition with food crop and high oil content. However, the cost of biofuel production from microalgae is still not competitive with petroleum fuel. The literature review of the three most favorable conversion processes: esterification, pyrolysis, and hydrothermal liquefaction (HTL) is presented. The cost of producing pyrolysis oil from pyrolysis process is the lowest because pyrolysis oil can be utilized directly while the crude biodiesel and bio crude from esterification and HTL require further upgrading processes. In this study, cultivated Coelastrum Sphaericum is dewatered by flocculating with sodium hydroxide and dolomite. The biomass is then filtered and dried before being fed into a continuous pyrolysis reactor. The pyrolysis yield from Coelastrum Sphaericum is $41.17 \%, 27.55 \%$, and $31.28 \%$ wt. for liquid, solid and gas respectively. The main composition of liquid yield is diesel and heavy oil. The total cost of microalgae pyrolysis oil is studied from interviewing research institute and conducting experiment. Without dewatering and labor cost, the cost of microalgae pyrolysis oil is 249.15 baht/liter.
\end{abstract}

Key words: Pyrolysis Oil, Microalgae, Dewatering.

\section{INTRODUCTION}

The world energy consumption has increased continuously since the industrial revolution in 1850, while the fossil energy sources, formed by natural process, have been depleted. The price of fossil fuel has increased dramatically as the demand is much more than supply and production. There are various sources of renewable energy to replace fossil fuel such as biomass, wind, hydropower, geothermal and solar. However, these sources of renewable energy still have restrictions on supply and production yield. This is particularly the case for biomass, although an agricultural waste, is still not produced in sufficient quantities to replace fossil fuel.

Microalgae are one of the most promising sources of renewable energy. It contains protein, carbohydrate and lipid with high oil content. Some species have oil content more than 80 percent per dry weight [1]. Thus, microalgae are one of the best feedstocks to produce biofuel [2-5].

Photosynthesis of microalgae uses carbon dioxide, water and sunlight to produce oxygen and glucose. The benefit of using microalgae to produce energy is that it can reduce GHGs and increase oxygen for the atmosphere. Moreover, microalgae can be grown in small raceway pond or photobioreactor so it does not have to compete with food crops for arable land and their growth rate is very high. It takes two weeks from the start to be fully grown and $3 \%$ of area in the U.S. for microalgae production can produce $50 \%$ of diesel that are using in the United States [1]. Microalgae are classified as the ${ }^{\text {rd }}$ generation of biomass that has high potential to produce biofuel [6].

Tan, Show et al. presented the four conversion methods to produce bioenergy from microalgae shown in Fig. 1 [7]. The three most preferable techniques from recent literature are esterification to produce crude biodiesel, liquefaction to produce bio crude and pyrolysis to produce pyrolysis oil.

Transesterification of microalgae has 6 processes, as shown in Fig. 2. The cost of production is still sky-high, not only from dewatering process, but also from solvent extraction and solvent removal. Moreover, the different cell size and cell wall chemistry of algal make it difficult and costly to extract only lipid from the cell while considering proteins and carbohydrates as waste [8]. It needs a breakthrough technology to significantly cut the process cost of transesterification to compete with the fossil-based fuels [9].

Pyrolysis of microalgae has 5 processes, as shown in Fig. 3. Pyrolysis oil from microalgae is most suitable for fuel as it allows full conversion of microalgae components to oil [10]. Yield of pyrolysis can have up to $75 \%$ of bio oil by varying pyrolysis condition [11]. Normally, dewatering process of microalgae is by done by centrifuging and drying to have less than $10 \%$ water content which consumes a lot of energy.

Hydrothermal liquefaction (HTL) of microalgae requires the lowest number of processes to produce bio oil from microalgae, as shown in figure 4. HTL of microalgae has only 4 processes to produce bio crude but the bio crude still needs to be further refined to produce usable biofuel. Its main advantage is that because HTL is carried out at high pressure and temperature in water, the microalgae feedstock do not need to be dried.

A summary of dewatering method, conversion efficiency, moisture content, type of biofuel, and total cost of the three preferable conversion processes has been presented in Table 1 .

To compare the cost among these three processes of biofuel production from microalgae, pyrolysis could be the lowest. Pyrolysis oil from microalgae can be used directly in residential heaters, small commercial boilers, engines, or marine applications in accordance to standard specification for pyrolysis liquid biofuel ASTM D7544, while crude biodiesel from esterification and bio crude from HTL must go through a costly upgraded before utilization [22, 23]. Moreover, direct pyrolysis can convert all components from microalgae to biofuel but esterification extracts only lipid to biodiesel. Biofuel yield of direct pyrolysis is approximately $7 \%$ greater than HTL which can be called indirect pyrolysis [24].

In order to produce a low cost pyrolysis oil from microalgae for commercialization, Xu et al. has concluded that the energy consumption and cost of dewatering wet microalgae are the main difficulty because of the moisture content of the harvested microalgae [37]. The dewatering efficiency has to be highly 
improved by using the low cost drying techniques. The energy consumed from dewatering is about $84.9 \%$ of energy consumption from the total biofuel production from microalgae [16]. The price of microalgae pyrolysis oil studied by Thilakaratne et al. is 1.80 USD/liter and 1.49 USD/liter for thermal drying prior to catalytic pyrolysis and mechanical dewatering prior to catalytic pyrolysis, respectively [36]. Mechanical dewatering can help reduce cost from the process by up to $17.2 \%$. From recent research, the cost of harvesting and dewatering is in the range of $0.5-2 \mathrm{EUR} / \mathrm{kg}$ for dilute solutions with flocculation from open cultivation systems [25].

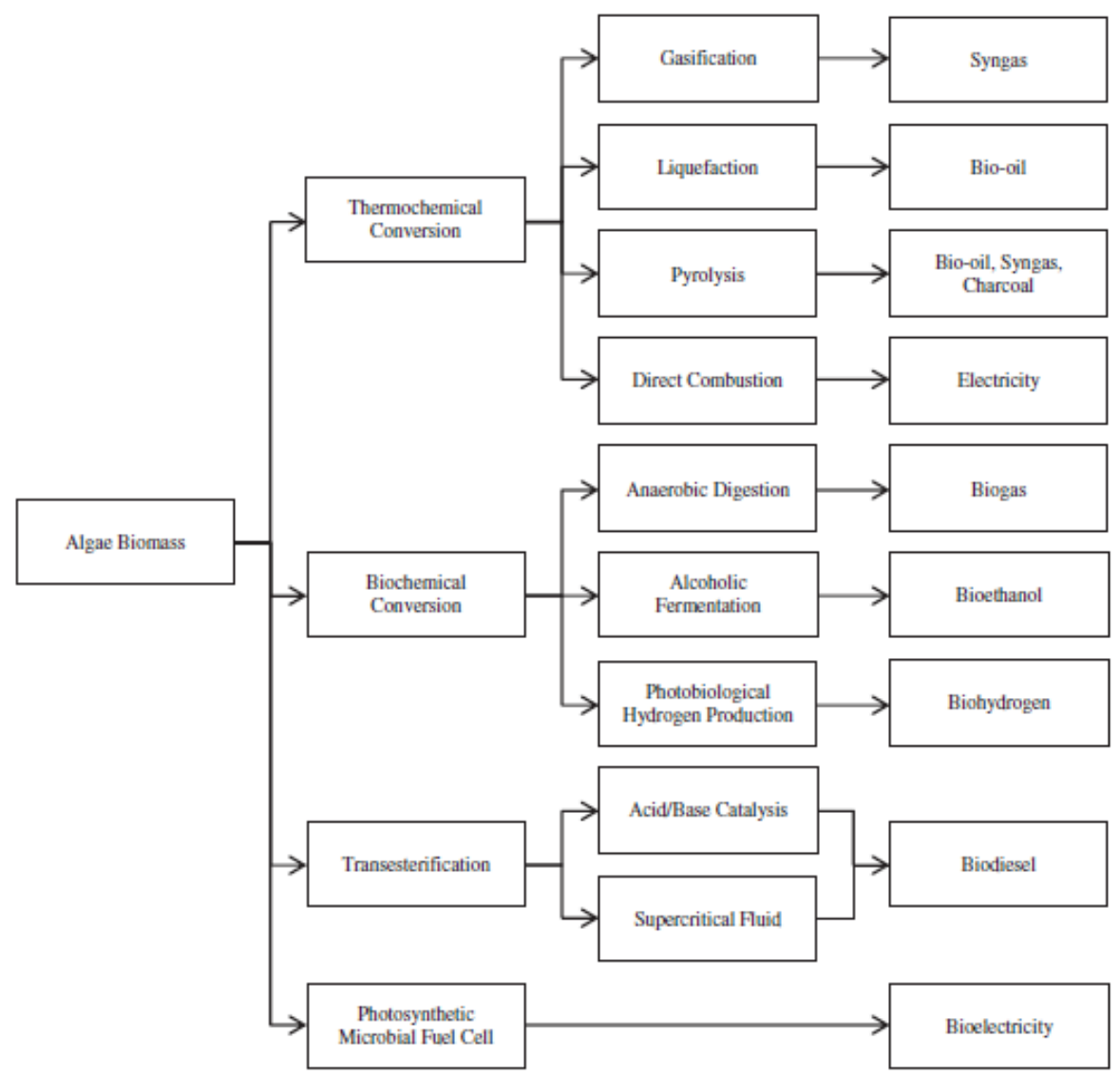

Fig. 1: Summary of potential microalgae biomass conversion processes [7].

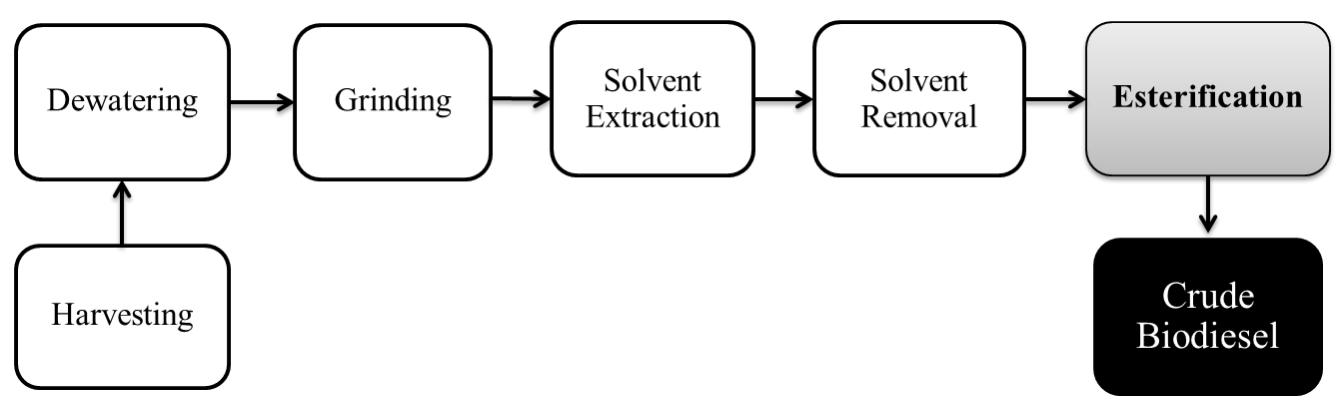

Fig. 2: The process of producing biodiesel from microalgae by esterification.

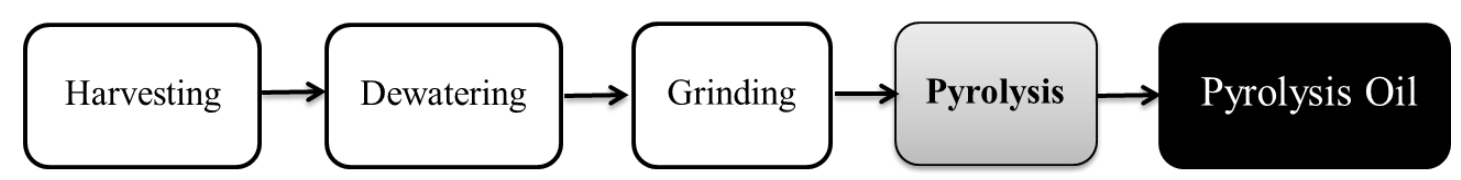

Fig. 3: The process of producing pyrolysis oil from microalgae by pyrolysis.

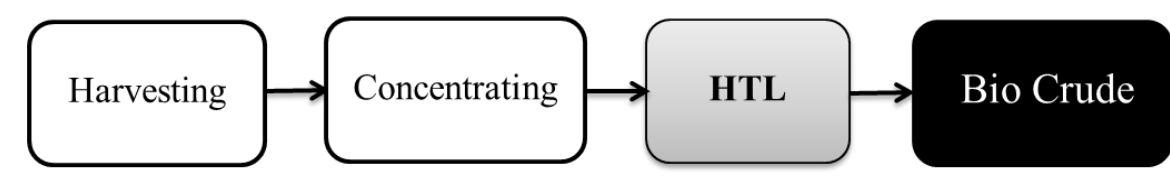

Fig. 4: The process of producing bio oil from microalgae by HTL. 
Citation: Suppalerk Aramkitphotha, 2018. A Low Cost Pyrolysis Oil Production From Microalgae. Advances in Natural and Applied Sciences., 12(8): 39-43. DOI: $10.22587 /$ anas.2018.12.8.8

Table 1: The summary of dewatering method, conversion efficiency, moisture content and total cost of conversion process to produce biofuel from microalgae.

\begin{tabular}{|l|l|l|l|l|l|l|}
\hline Process & Dewatering Method & $\begin{array}{l}\text { Conversion } \\
\text { Efficiency (\%) }\end{array}$ & $\begin{array}{l}\text { Moisture } \\
\text { Content } \\
\text { Before Process }\end{array}$ & $\begin{array}{l}\text { Type } \\
\text { biofuel }\end{array}$ & Total Cost & Reference \\
\hline Esterification & $\begin{array}{l}\text { Flocculation, The } \\
\text { Centrifuge, Thermal } \\
\text { Drying }\end{array}$ & $65-95 \%$ & $10-15 \%$ & $\begin{array}{l}\text { Crude } \\
\text { biodiesel }\end{array}$ & High & {$[\underline{12-16}]$} \\
\hline HTL & Concentrating & $33-58 \%$ & $80-90 \%$ & Bio crude & Medium & {$[\underline{17-19]}$} \\
\hline Pyrolysis & $\begin{array}{l}\text { Floculation, Thermal } \\
\text { Centrifuge, Thermal } \\
\text { Drying }\end{array}$ & $30-75 \%$ & $10 \%$ & Pyrolysis oil & Medium & {$[\underline{11}, \underline{21}]$} \\
\hline
\end{tabular}

The summary of dewatering techniques of wet microalgae in literature is presented in Table 2.

Table 2: Summary of dewatering techniques of wet microalgae in literature.

\begin{tabular}{|c|c|c|c|}
\hline Dewatering Technique & Advantage & Disadvantage & Reference \\
\hline Sun Drying & Lowest cost & $\begin{array}{l}\text { - Time consuming } \\
\text { - Need surface to be directly exposed to } \\
\text { the sun }\end{array}$ & {$[26]$} \\
\hline Flocculation & Low cost & $\begin{array}{l}\text { - Time consuming and opportunity to be } \\
\text { rotten or cell condition can be changed. } \\
\text { - Low concentration, need to be } \\
\text { centrifuged }\end{array}$ & {$[27,28]$} \\
\hline Chemical Flocculation & $\begin{array}{l}\text { - Less harvesting time, more } \\
\text { productivity } \\
\text { - Can be used with various } \\
\text { strain of microalgae } \\
\text { - Low cost }\end{array}$ & - $\quad$ Chemical contamination in microalgae & {$[29,30]$} \\
\hline Filtration & $\begin{array}{l}\text { - } \quad \text { Low cost, simple process } \\
\text { - } \quad \text { Preserve cell from damaging }\end{array}$ & $\begin{array}{l}-\quad \text { Can be used only for macro algae and } \\
\text { some type of microalgae }(>70 \mathrm{~nm})\end{array}$ & {$[28,31]$} \\
\hline Centrifugation & $\begin{array}{l}\text { - } \quad \text { General method to } \\
\text { concentrate algal biomass }\end{array}$ & $\begin{array}{l}\text { - } \quad \text { Cell damaging due to shear force } \\
\text { - High cost }\end{array}$ & [32] \\
\hline Oven Drying & $\begin{array}{l}\text { - Fast (12 hours), high } \\
\text { efficiency }\end{array}$ & - $\quad$ Expensive & [33] \\
\hline Freeze Drying & - $\quad$ Help reduce cell breaking & $\begin{array}{l}\cdot \quad \text { Expensive } \\
-\quad \text { Longer time than oven drying ( } 24 \\
\text { hours) }\end{array}$ & [34] \\
\hline
\end{tabular}

Auto flocculation is another low cost method to dewater wet microalgae when $\mathrm{pH}$ is more than 9. This sometime happens during photosynthesis of microalgae [30,35]. In principle, small particles such as algae have a surface charge that repel from one another. In some cases, magnesium hydroxide (brucite) or calcium carbonate (calcite) are used to decrease acidity in order to increase auto flocculation. Harith et al. tested $\mathrm{pH} 10.2$ by adding $\mathrm{NaOH}$ or $\mathrm{KOH}$ that can increase the harvesting efficiency to $90 \%$ [38].

Various techniques in literature have been studied to reduce the cost of dewatering process, but there is still a gap when comparing the total pyrolysis oil cost with the conventional fossil fuel price. This paper will focus on the lowest cost technique of dewatering to produce pyrolysis oil from microalgae by utilizing low cost alkali, sodium hydroxide $(\mathrm{NaOH})$ and dolomite (mixtures of calcium and magnesium hydroxides). A preliminary economic evaluation of each process is included in this study.

\section{MATERIAL AND METHOD}

Coelastrum Sphaericum cultivated in raceway pond from Thailand Institute of Scientific and Technological Research (TISTR) is used in this experiment. The sodium hydroxide and dolomite are obtained from the local chemical supplier. Batches of 1,000 $\mathrm{ml}$ of algal biomass are prepared at different $\mathrm{pH}$ from 8 to 12 by controlling the amount of $\mathrm{NaOH}$ and dolomite and tested for auto flocculation, as shown in Fig. 5. After filtering, a floe is dried by thermal dryer $105^{\circ} \mathrm{C}$ for 12 hours. Dry microalgae (moisture less than 10\%) are fed into continuous pyrolysis reactor shown in Fig. 6 while varying temperature, feed rate, and N2 flow rate. An Agilent GC-MS 7890A/5975C series (Agilent Technologies, Santa Clara, CA) is used for GC analysis of microalgae pyrolysis oil in accordance to ASTM D2887. The result was analyzed by simulated distillation software (Agilent Technologies) for chemical composition according to the distillation boiling range of hydrocarbon. The cost of pyrolysis oil from microalgae consists of cultivation cost, harvesting cost, dewatering cost, drying cost, and pyrolysis cost. The cultivation cost is from interviewing TISTR while the rest are from lab-scale experiment at Chulalongkorn University, Center of Learning for the Region (CLNR).

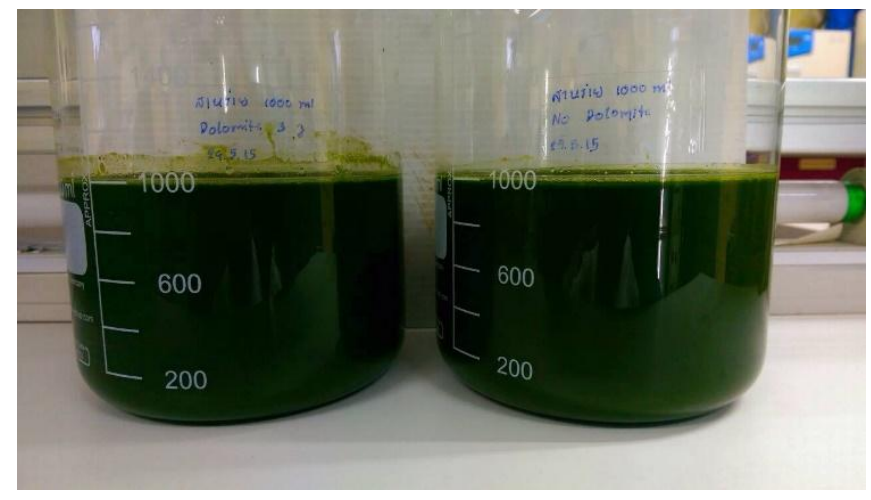


Fig. 5: 1,000 $\mathrm{ml}$ of algal biomass sample varying $\mathrm{NaOH}$ and Dolomite.

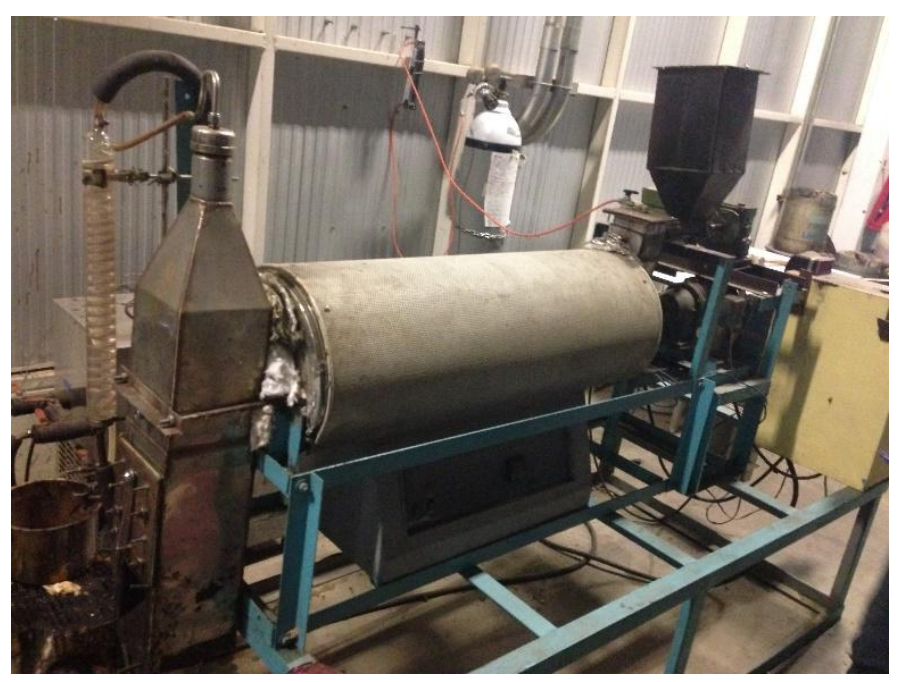

Fig. 6: Continuous pyrolysis reactor

\section{RESULT AND DISCUSSION}

The result of microalgae pyrolysis yield by varying temperature, feed rate and nitrogen rate is shown in Table 3. From this table, the best yield of pyrolysis oil is from pyrolysis process at temperature $500^{\circ} \mathrm{C}$, feed rate $100 \mathrm{rpm}$ and nitrogen rate at $200 \mathrm{ml} / \mathrm{min}$ and the yield of pyrolysis oil, solid, and gas is $41.17 \%$, $27.55 \%$, and $31.28 \%$ wt. respectively. The auto flocculation effects on dewatering are still under investigation and are outside of the scope of this study.

Table 3: The yield of microalgae pyrolysis by varying temperature, feed rate, and nitrogen rate.

\begin{tabular}{|c|c|c|c|c|c|c|}
\hline $\begin{array}{l}\text { Dry Microalgae } \\
\text { (g) }\end{array}$ & Temperature $\left({ }^{\circ} \mathrm{C}\right)$ & $\begin{array}{l}\text { Feed rate } \\
(\mathbf{r p m})\end{array}$ & $\begin{array}{ll}\begin{array}{l}\text { Nitrogen } \\
(\mathrm{ml} / \mathrm{min})\end{array} & \text { rate }\end{array}$ & Gas (\%wt.) & Liquid (\% wt.) & Solid (\% wt.) \\
\hline 150 & 400 & 150 & 200 & 23.23 & 6.03 & 70.74 \\
\hline 150 & 450 & 150 & 200 & 31.18 & 18.78 & 50.04 \\
\hline 150 & 500 & 150 & 200 & 33.30 & 22.17 & 44.53 \\
\hline 150 & 550 & 150 & 200 & 45.83 & 19.45 & 34.71 \\
\hline 150 & 600 & 150 & 200 & 51.10 & 17.73 & 31.18 \\
\hline 150 & 500 & 50 & 200 & 37.28 & 24.84 & 26.52 \\
\hline 150 & 500 & 100 & 200 & 44.64 & 26.43 & 28.92 \\
\hline 150 & 500 & 150 & 200 & 33.30 & 22.17 & 44.53 \\
\hline 150 & 500 & 200 & 200 & 31.58 & 12.79 & 55.63 \\
\hline 150 & 500 & 250 & 200 & 27.84 & 6.86 & 65.30 \\
\hline 150 & 500 & 100 & 50 & 57.34 & 19.57 & 23.09 \\
\hline 150 & 500 & 100 & 100 & 38.82 & 32.66 & 28.52 \\
\hline 150 & 500 & 100 & 150 & 33.95 & 39.77 & 26.28 \\
\hline 150 & 500 & 100 & 200 & 31.28 & 41.17 & 27.55 \\
\hline 150 & 500 & 100 & 250 & 31.51 & 40.25 & 28.24 \\
\hline
\end{tabular}

The result from simulated distillation program of microalgae pyrolysis oil is shown in Table 4. More than $80 \%$ of microalgae pyrolysis oil is diesel and heavy oil with the range of boiling point more than $250^{\circ} \mathrm{C}$.

Table 4: Hydrocarbon composition of microalgae pyrolysis oil.

\begin{tabular}{|l|l|l|l|}
\hline Hydrocarbon Composition & Number of Carbon & Boiling Point $\left({ }^{\circ} \mathbf{C}\right)$ & \% Weight \\
\hline Naphtha & C5-C12 & IBP-200 & 11.14 \\
\hline Kerosene & C12-C15 & $200-250$ & 6.86 \\
\hline Diesel & C15-C33 & $250-370$ & 21.00 \\
\hline Heavy Oil & $>$ C33 & $370-$ FBP & 61.00 \\
\hline
\end{tabular}

The cultivation cost, consisted of nutrient and electricity, for 20,000 liter of algae is in the range of $600-1,000$ baht depending on the type of nutrient and controlled system. The yield of dry microalgae is around $0.3-0.5 \%$ depending on the condition. Thus, it can be assumed from the interview result that the best cultivation cost is $60-100$ baht per $1 \mathrm{~kg}$ dry microalgae.

The electricity cost of $1 \mathrm{~kg}$ dry microalgae from the thermal dryer and continuous pyrolysis reactor is 6.725 and $8.275 \mathrm{~kW}$.hr (unit) respectively. It can be calculated that the total electricity cost of pyrolysis is 48.73 baht per $1 \mathrm{~kg}$ dry microalgae (the electricity cost assumed from Thailand Metropolitan Electricity Authority (MEA) of small business under $12 \mathrm{kV}$ within 150 unit per month is $3.2484 \mathrm{baht} / \mathrm{unit}$ ).

From this result, the total cost of $1 \mathrm{~kg}$ of microalgae pyrolysis oil without dewatering and labor cost is 264.10 baht or 249.15 baht/liter (the density of microalgae pyrolysis oil is $1.06 \mathrm{~kg} / \mathrm{liter}$ ).

Conclusion:

In conclusion, dewatering cost is still the bottleneck to apply microalgae biofuel for commercialization. It requires a breakthrough in cost-effective techniques to overcome the problem. This paper mainly focused on the experiment to have lowest dewatering cost of microalgae by using auto flocculation technique with dolomite and sodium hydroxide.

This study also demonstrates that pyrolysis of Coelastrum Sphaericum can obtain $41.17 \%$ of pyrolysis oil which is $82 \%$ diesel and heavy oil. The total cost of microalgae pyrolysis oil is still too high to replace fossil fuel (249.15 baht per liter without dewatering and labor cost). However, the benefits of utilizing 
microalgae for energy may overcome this drawback. The continuous development on microalgae species and the cultivation techniques to increase yield and decrease their nutrition cost would provide a strong foundation for microalgae as a source of biofuel. Although presently the total cost of biofuel from microalgae cannot compete with conventional petroleum fuel, it will be competitive once the fossil fuel has depleted.

\section{REFERENCES}

[1] Chisti, Y., 2007. Biodiesel from microalgae. Biotechnol Adv., 25: 294-306.

[2] Wang, H.Y., D. Bluck and B.J. Van Wie, 2014. Conversion of microalgae to jet fuel: Process design and simulation. Bioresource Technology, 167(0): 349357.

[3] Huang, J., et al., 2015. Biodiesel production from microalgae oil catalyzed by a recombinant lipase. Bioresource Technology, 180(0): 47-53.

[4] Lokesh, K., et al., 2015. Life cycle greenhouse gas analysis of biojet fuels with a technical investigation into their impact on jet engine performance. Biomass and Bioenergy, 77(0): 26-44.

[5] Jazzar, S., et al., 2015. Direct supercritical methanolysis of wet and dry unwashed marine microalgae (Nannochloropsis gaditana) to biodiesel. Applied Energy, 148(0): 210-219.

[6] Dragone, G., et al., 2010. Third generation biofuels from microalgae.

[7] Tan, C.H., et al., 2015. Novel approaches of producing bioenergies from microalgae: A recent review. Biotechnology Advances.

[8] Na, J.G., et al., 2012. Decarboxylation of microalgal oil without hydrogen into hydrocarbon for the production of transportation fuel. Catalysis Today, 185(1): 313-317.

[9] Ramos Tercero, E.A., G. Domenicali and A. Bertucco, 2014. Autotrophic production of biodiesel from microalgae: An updated process and economic analysis. Energy, 76(0): 807-815.

[10] Du, Z., et al., 2013. Catalytic pyrolysis of microalgae and their three major components: Carbohydrates, proteins, and lipids. Bioresource Technology, 130: 777-782.

[11] Marcilla, A., et al., 2013. A review of thermochemical conversion of microalgae. Renewable and Sustainable Energy Reviews, 27(0): 11-19.

[12] Ehimen, E.A., Z.F. Sun and C.G. Carrington, 2010. Variables affecting the in situ transesterification of microalgae lipids. Fuel, 89(3): 677-684.

[13] Shin, H.Y., et al., 2014. Lipid extraction from Scenedesmus sp. microalgae for biodiesel production using hot compressed hexane. Fuel, $130: 66-69$.

[14] Xu, L., et al., 2011. Assessment of a dry and a wet route for the production of biofuels from microalgae: Energy balance analysis. Bioresource Technology, 102(8): 5113-5122.

[15] Torres, S., et al., 2017. Direct transesterification of microalgae biomass and biodiesel refining with vacuum distillation. Algal Research, $28: 30-38$.

[16] Lardon, L., et al., 2009. Life-cycle assessment of biodiesel production from microalgae. Environmental science \& technology, 43(17): 6475-6481.

[17] Jones, S.B., et al., 2014. Process design and economics for the conversion of algal biomass to hydrocarbons: whole algae hydrothermal liquefaction and upgrading. Pacific Northwest National Laboratory.

[18] Eboibi, B.E.O., et al., 2014. Hydrothermal liquefaction of microalgae for biocrude production: Improving the biocrude properties with vacuum distillation. Bioresource Technology, 174: 212-221.

[19] Frank, E., et al., 2013. Life cycle comparison of hydrothermal liquefaction and lipid extraction pathways to renewable diesel from algae. Mitigation and Adaptation Strategies for Global Change, 18(1): 137-158.

[20] Brownsort, P.A., 2009. Biomass pyrolysis processes: performance parameters and their influence on biochar system benefits.

[21] Duan, P., et al., 2015. Co-pyrolysis of microalgae and waste rubber tire in supercritical ethanol. Chemical Engineering Journal, 269(0): $262-271$.

[22] Tabernero, A., E.M. Martín del Valle and M.A. Galán, 2012. Evaluating the industrial potential of biodiesel from a microalgae heterotrophic culture: Scaleup and economics. Biochemical Engineering Journal, 63(0): 104-115.

[23] Gerde, J.A., et al., 2013. Optimizing protein isolation from defatted and non-defatted Nannochloropsis microalgae biomass. Algal Research, 2(2): 145-153.

[24] Vardon, D.R., et al., 2012. Thermochemical conversion of raw and defatted algal biomass via hydrothermal liquefaction and slow pyrolysis. Bioresource Technology, 109(0): 178-187.

[25] Fasaei, F., et al., 2018. Techno-economic evaluation of microalgae harvesting and dewatering systems. Algal Research, 31: 347-362.

[26] Guldhe, A., et al., 2014. Efficacy of drying and cell disruption techniques on lipid recovery from microalgae for biodiesel production. Fuel, $128(0)$ : 46-52.

[27] Williams, P.J.1.B. and L.M. Laurens, 2010. Microalgae as biodiesel \& biomass feedstocks: review \& analysis of the biochemistry, energetics \& economics. Energy \& Environmental Science, 3(5): 554-590.

[28] Li, Y., et al., 2008. Biofuels from microalgae. Biotechnology progress, 24(4): 815-820.

[29] Chang, Y.R. and D.J. Lee, 2012. Coagulation-membrane filtration of Chlorella vulgaris at different growth phases. Drying Technology, 30(11-12): 13171322.

[30] Vandamme, D., I. Foubert and K. Muylaert, 2013. Flocculation as a low-cost method for harvesting microalgae for bulk biomass production. Trends in Biotechnology, 31(4): 233-239.

[31] Zhang, X., et al., 2010. Harvesting algal biomass for biofuels using ultrafiltration membranes. Bioresource Technology, 101(14): $5297-5304$.

[32] Christenson, L. and R. Sims, 2011. Production and harvesting of microalgae for wastewater treatment, biofuels, and bioproducts. Biotechnology advances, 29(6): 686-702.

[33] Ansari, F.A., et al., 2018. Evaluation of various cell drying and disruption techniques for sustainable metabolite extractions from microalgae grown in wastewater: A multivariate approach. Journal of Cleaner Production, 182: 634-643.

[34] Brennan, L. and P. Owende, 2010. Biofuels from microalgae - A review of technologies for production, processing, and extractions of biofuels and coproducts. Renewable and Sustainable Energy Reviews, 14(2): 557-577.

[35] Schlesinger, A., et al., 2011. Method and system for efficient harvesting of microalgae and cyanobacteria. Google Patents.

[36] Thilakaratne, R., M.M. Wright and R.C. Brown, 2014. A techno-economic analysis of microalgae remnant catalytic pyrolysis and upgrading to fuels. Fuel, 128(0): 104-112.

[37] Xu, L., et al., 2011. Assessment of a dry and a wet route for the production of biofuels from microalgae: Energy balance analysis. Bioresource Technology, 102(8): 5113-5122.

[38] Harith, Z., et al., 2009. Effect of different flocculants on the flocculation performance of microalgae, Chaetoceros calcitrans, cells. 8: 5971-5978. 